PRÁVNE ROZPRAVY ON-SCREEN II. - Sekcia súkromného práva

online vedecká konferencia - 13. november 2020

\title{
ZMENA SÍDLA STÁLEHO ROZHODCOVSKÉHO SÚDU S CIELOM VYHNÚŤ SA ZASTAVENIU PREBIEHAJÚCICH \\ ROZHODCOVSKÝCH KONANÍ?
}

RELOCATION OF A PERMANENT ARBITRAL TRIBUNAL

IN ORDER TO AVOID STOPPING ONGOING ARBITRATION

PROCEEDINGS?

Miloš Levrinc ${ }^{1}$

DOI: https://doi.org/10.24040/pros.13.11.2020.ssp.93-105

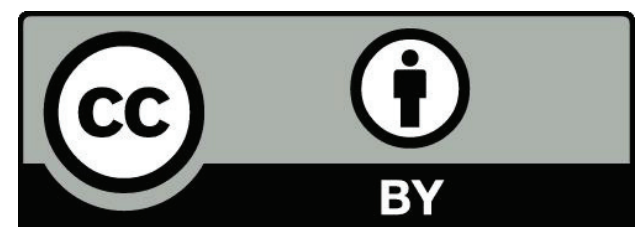

\begin{abstract}
Abstrakt
Podl'a intertemporálnych ustanovení uvedených v § 54c zákona č. 244/2002 Z. z. o rozhodcovskom konaní (k úpravám účinným od 01.01.2017) stály rozhodcovský súd zriadený podl’a doterajších predpisov, ktorého zriad'ovatel' nespĺn̆a podmienky ustanovené týmto zákonom pre zriad’ovatel’a stáleho rozhodcovského súdu, nemôže po 31. decembri 2016 uskutočňovat' rozhodcovské konania podl'a tohto zákona a vydávat' rozhodcovské rozhodnutia. Príspevok sa venuje osudu rozhodcovských konaní vedených stálym rozhodcovským súdom, ktorého zriad'ovatel' nespĺn̆a podmienky novej právnej úpravy po 31.12.2016, avšak pred nastúpením účinkov novej právnej úpravy zmeni sídlo stáleho rozhodcovského súdu, prípadne vykoná zmeny týkajúce sa zriad’ovatel’a.
\end{abstract}

Kl’účové slová

Stály rozhodcovský súd. Sídlo rozhodcovského konania. Rozhodcovská zmluva. Zastavenie rozhodcovského konania.

\begin{abstract}
According to the intertemporal provisions stated in $\$ 54$ c of Act no. 244/2002 Z.z. on Arbitration (to adjustments effective from 01.01.2017) a permanent arbitration tribunal established under existing regulations, the founder of which does not meet the conditions established by this Act for the founder of a permanent arbitration tribunal, may not conduct arbitration proceedings under this Act and issue arbitration awards after 31 December 2016. The article deals with fate of arbitration proceedings conducted by a permanent arbitral tribunal, the founder of

\footnotetext{
${ }^{1}$ Autor príspevku pôsobí od r. 2002 na Právnickej fakulte UMB v Banskej Bystrici, v r. 2008 úspešne ukončil doktorandské štúdium vykonaním dizertačnej skúšky a obhajobou dizertačnej práce na tému- Zmluvy v medzinárodnom obchode. V súčasnosti pôsobí ako odborný asistent na Katedra medzinárodného, európskeho práva a právnej komunikácie.
} 


\section{PRÁVNE ROZPRAVY ON-SCREEN II. - Sekcia súkromného práva}

online vedecká konferencia - 13. november 2020

which does not meet the conditions of the new legislation after 31 December 2016, however, before the effects of the new legislation take effect, it shall change the seat of the permanent arbitral tribunal, or make changes concerning the founder.

\section{Keywords}

Permanent arbitration tribunal. Seat of arbitration proceedings. Arbitration agreement. Suspension of arbitration proceedings.

\section{Úvod}

Zákonom č. 336/2014 Z. z. ${ }^{2}$ a následne Zákonom č. 125/2016 Z. z. ${ }^{3}$ boli v Slovenskej republike zásadne zmenené podmienky zriad’ovania stálych rozhodcovských súdov, kde doposial' značne liberálna úprava, umožňujúca ktorejkol'vek právnickej osobe zriadit' stály rozhodcovský súd, bola nahradená novou právnou úpravou, ktorá umožňuje zriadit' stály rozhodcovský súd iba úzkemu okruhu subjektov, predovšetkým subjektom komorového typu. Uvedené zaiste súvisí s úmyslom zákonodarcu sprísnit' kritériá pre zriad'ovanie stálych rozhodcovských súdov s ohl'adom predovšetkým na kvalitu samotného rozhodcovského konania, ktoré nemôžu garantovat' akékol’vek subjekty súkromného práva, ale len úzko špecializované subjekty, s určitým renomé a pripravenost'ou zriadit' kvalitnú rozhodcovskú inštitúciu s odborne zdatnou personálnou základňou. Dovtedajšie rozhodcovské konania, vedené stálymi rozhodcovskými súdmi, ktorých zriad’ovatelia nespíňajú uvedené nové zákonné podmienky sa zastavujú, pričom zriad’ovatel' je následne v zákonnej lehote povinný zrušit’ stály rozhodcovský súd. Článok sa pokúša reagovat' na prípadné následky konania niektorých rozhodcovských inštitúcií, resp. ich zriad'ovatel'ov, ktorí v snahe vyhnút' sa likvidačným účinkom novej právnej úpravy pred jej účinnost'ou alokujú stály rozhodcovský súd a rozhodcovské konanie z dosahu účinkov právneho poriadku SR. Ciel'om tohto článku je zároveň pokúsit' sa analyzovat' účinky takéhoto konania s poukazom na platnú právnu úpravu; okrem iného, vzhl'adom na určitý časový posun od prijatia novej právnej úpravy, poukázat' na vybranú judikatúru reagujúcu na takúto ,,alokáciu“ stáleho rozhodcovského konania.

\footnotetext{
${ }^{2}$ Zákon č. 336/2014 Z.z., ktorým sa mení a dopíňa zákon č. 244/2002 Z. z. o rozhodcovskom konaní v znení neskorších predpisov a o zmene a doplnení zákona č. 371/2004 Z. z. o sídlach a obvodoch súdov Slovenskej republiky a o zmene zákona č. 99/1963 Zb. Občiansky súdny poriadok v znení neskorších predpisov.

3 Zákon č. 125/2016 Z.z. o niektorých opatreniach súvisiacich s prijatím Civilného sporového poriadku, Civilného mimosporového poriadku a Správneho súdneho poriadku a o zmene a doplnení niektorých zákonov.
} 


\section{PRÁVNE ROZPRAVY ON-SCREEN II. - Sekcia súkromného práva}

online vedecká konferencia - 13. november 2020

\section{Jadro}

„Rozhodcovské konanie je inštitútom súkromného práva, v ktorom rozhodcovia ako osoby súkromného práva rozhodujú spory na základe súkromnoprávneho aktu účastníkov konania. Rozhodcom ani rozhodcovským súdom nie je formálne ani materiálne zverený výkon verejnej moci. Nemožno ho charakterizovat' ako súd v zmysle čl. 141 Ústavy SR.“4

Podla ustálenej rozhodovacej činnosti Ústavného súdu ČR „charakter rozhodčí činnosti je založený smlouvou delegující vůli stran a její výsledek je činností narovnávající ve smyslu § 585 obč. zák. Výsledek pak je kvalifikovanou formou závazku a jako takový je též závazný. Rozhodce nenalézá právo, ale tvoří (eventuálne napevno staví, vyjasňuje, tedy narovnává) závazkový vztah v zastoupení stran. Jeho moc tedy není delegovaná svrchovanou moci státu, ale pochází od soukromé vlastní moci stran určovat si svůj osud, kterou mu svěřily. "5

Základom každého rozhodcovského konania je existencia rozhodcovskej zmluvy, ktorou sa strany podriadili právomoci rozhodcovského súdu, nakol'ko rozhodcovské konanie je možné začat’ iba na návrh niektorej zo zmluvných strán. Rozhodcovská zmluva sa môže uzavriet' bud' ako osobitná zmluva o tom, že všetky alebo niektoré spory, ktoré medzi stranami vzniknú v určitom zmluvnom alebo inom právnom vzt'ahu sa rozhodnú v rozhodcovskom konaní, alebo ako rozhodcovská doložka k zmluve, ktorá bola medzi stranami uzavretá a zakladá medzi nimi konkrétny právny vzt’ah.

Neodmyslitel'nou súčast'ou akéhokol'vek rozhodcovského konania je rozhodcovský súd, ktorým sa podl'a ust. § 7 Zákona č. 244/2002 Z. z. o rozhodcovskom konaní (d’alej aj ako „zákon“) rozhodcovským súdom rozumie jediný rozhodca alebo viacerí rozhodcovia. Preto v prípade ak zákon používa pojem rozhodcovský súd je potrebné pod tým rozumiet' konkrétneho rozhodcu, konkrétnych rozhodcov, ak pre rozhodovanie sporu boli dojednaní (ustanovení) viacerí rozhodcovia (rozhodcovský senát). Zákon d’alej na inom mieste, v $§ 12$ upravuje postavenie tzv. stáleho rozhodcovského súdu. Z doteraz uvedeného môžeme rozlišovat' rozhodcovské súdy ad hoc a tzv. stále rozhodcovské súdy.

Aj v prípade stáleho rozhodcovského súdu (inštitucionálnej arbitráže) budeme v konečnom dôsledku hovorit' o konkrétnom rozhodcovi, rozhodcoch zvolených

\footnotetext{
${ }^{4}$ Ústavný súd SR, Plz. ÚS 5/2015.

5 Ústavný súd ČR, Pl. ÚS 37/98 - Gyárášs, J., Števček, M., a kol. . Zákon o rozhodcovskom konaní. Komentár. Praha: C.H. BECK, 2016, s. 1.
} 


\section{PRÁVNE ROZPRAVY ON-SCREEN II. - Sekcia súkromného práva}

online vedecká konferencia - 13. november 2020

(ustanovených) na rozhodovanie sporu v súlade s procedurálnymi predpismi stáleho rozhodcovského súdu podl'a $\S 13$ a 14, ktoré sú platné v čase začatia rozhodcovského konania pred týmto stálym rozhodcovským súdom, ak sa zmluvné strany nedohodli inak. ${ }^{6}$

I ked’ z ust. § 12 ods. 4 nepriamo vyplýva oprávnenie stáleho rozhodcovského súdu uskutočňovat' rozhodcovské konania a vydávat' rozhodcovské rozhodnutia, v konečnom dôsledku tu hovoríme o konkrétnom rozhodcovi, prípadne o rozhodcoch, ktorý bol dojednaný, ustanovený (boli dojednaní, ustanovení) na rozhodovanie konkrétneho sporu zo zoznamu rozhodcov vedeným stálym rozhodcovským súdom, pretože stály rozhodcovský súd nemá právnu subjektivitu, nejde teda o právnickú osobu. ${ }^{7}$ „Stály rozhodcovský súd nie je teda „entitou“, ktorá vedie rozhodcovské konanie a vydáva rozhodcovské rozhodnutia. “8 Naproti tomu česká právna úprava rozhodcovského konania ustanovuje: „Strany se mohou dohodnout, že o majetkových sporech mezi nimi, s výjimkou sporů ze smluv, které se spotřebitelem uzavírá podnikatel, sporů vzniklých v souvislosti s výkonem rozhodnutí a incidenčních sporů, k jejichž projednání a rozhodnutí by jinak byla dána pravomoc soudu nebo o nichž to stanoví zvláštní zákon, má rozhodovat jeden nebo více rozhodců anebo stálý rozhodčí soud (rozhodčí smlouva). "9

Ako už bolo naznačené $\mathrm{v}$ rozhodcovskej praxi možno preto rozlišovat' tzv. rozhodcovským konanie ad hoc a inštitucionalizované rozhodcovské konanie, ktoré je upravené v uvedenom ust. § 12 zákona.

Ad hoc rozhodcovské konanie (ad hoc arbitráž) prebieha a je ustanovované (dojednaná) pre konkrétny prípad, nepôsobí nepretržite za účelom uskutočňovania viacerých rozhodcovských konaní. Strany si za účelom rozhodnutia konkrétneho prípadu (sporu) dohodnú jedného alebo niekol'kých rozhodcov, ktorých si sami vyberú, resp. ich menuje stranami určená osoba. Rozhodcovské konanie je viazané ustanoveniami právnych noriem určených pre rozhodcovské konanie na území štátu, kde sa má rozhodcovské konanie uskutočnit' (lex arbitri). Naopak úlohou stálych rozhodcovských súdov (inštitucionálnych arbitráží) je uskutočňovanie rozhodcovských konaní a vydávanie rozhodcovských rozsudkov nepretržite po splnení zákonom stanovených podmienok. Tu môžeme hovorit’ aj o nepretržitej administratívnej podpore stáleho rozhodcovského súdu. V takomto prípade sa strany

\footnotetext{
${ }^{6} \S 12$ ods. 5 Zákona č. 244/2002 Z.z. v platnom znení k 01.01.2017.

${ }^{7}$ Najvyšší súd SR, sp. zn. 5 Obdo 20/2012.

${ }^{8}$ Gyárfáš, J., Števček, M., a kol. . Zákon o rozhodcovskom konaní. Komentár. Praha: C.H. BECK, 2016, s. 231.

${ }^{9} \S 2$ ods. 1 Zákona. č. 216/1994 Sb. o rozhodčím řízení a o výkonu rozhodčích nálezů, ve znění pozdějších předpisů (ČR).
} 


\section{PRÁVNE ROZPRAVY ON-SCREEN II. - Sekcia súkromného práva}

online vedecká konferencia - 13. november 2020

podrobujú štatútu a rokovaciemu poriadku, ktorého ustanovenia platia aj pre určenie miesta rozhodcovského konania. Zriad'ovanie stálych rozhodcovských súdov podlieha právnym predpisom štátu, na ktorého území majú sídlo.

Zákon č. 336/2014 Z. z. nanovo upravil zriadenie stáleho rozhodcovského súdu v § 12, pričom zriad'ovatel'om stáleho rozhodcovského súdu so sídlom na území Slovenskej republiky môže byt' len záujmové združenie právnických osôb, národný športový zväz, Slovenský olympijský výbor, Slovenský paralympijský výbor alebo komora zriadená zákonom. Právnická osoba je povinná na svoje náklady zriadit' a udržiavat' stály rozhodcovský súd, ak to ustanovuje osobitný predpis.

Podl’a ust. § 54b Prechodných ustanovení k úpravám účinným podla novely č. 336/2014 Z. z. od 1. Januára 2015 ustanovenia tohto zákona sa použijú aj na konania začaté pred 1. januárom 2015. Stály rozhodcovský súd zriadený pred 1. januárom 2015 musí do troch mesiacov po nadobudnutí účinnosti tohto zákona splnit' podmienky ustanovené týmto zákonom pre stále rozhodcovské súdy zriadené po 31. decembri 2014. Ak rozhodcovská zmluva odkazuje na stály rozhodcovský súd zriadený podl’a doterajších predpisov, ktorého pôvodný zriad'ovatel' nespĺn̆a od 1. januára 2015 podmienky ustanovené týmto zákonom pre zriad'ovatel'a nového stáleho rozhodcovského súdu a ak sa pôvodný zriad'ovatel' stáleho rozhodcovského súdu stane členom iného zriad'ovatel'a nového stáleho rozhodcovského súdu, aby sa splnili tieto podmienky, platí, že rozhodcovská zmluva odkazuje na nový stály rozhodcovský súd zriadený podl'a tohto zákona iným zriad’ovatel’om. To neplatí, ak sa zmluvné strany rozhodcovskej zmluvy dohodnú po 31.decembri 2014 inak alebo ak niektorá zo strán pred podaním žaloby na nový stály rozhodcovský súd podl’a predchádzajúcej vety podá návrh na začatie konania na všeobecnom súde. ${ }^{10}$

Zriad’ovanie stálych rozhodcovských súdov ešte viac sprísnila Novela č. 125/2016 Z. z., pričom ako zriad’ovatel'a vypustila záujmové združenia právnických osôb. Vychádzajúc zo spoločnej správa výborov „prax však ukázala, že vzhl’adom na neexistujúci dohl'ad štátu nad zriad'ovatel'mi stálych rozhodcovských súdov podl'a zákona č. $244 / 2002 \quad Z$ z. $z$. o rozhodcovskom konaní sa ukázalo, že je nevyhnutné túto reguláciu ešte sprísnit'. "11

Novely č. 336/2014 Z. z. a 125/2016 Z. z. reagovali na značný nárast rozhodcovských súdov, kde predchádzajúca právna úprava umožňovala zriadit’ rozhodcovský súd akoukol’vek

\footnotetext{
${ }^{10}$ Bližšie Csach, K. Intertemporalita novej úpravy rozhodcovského konania. Súkromné právo, 2015, č. 8, s. 1631.

${ }^{11}$ Tamtiež, s. 229.
} 


\section{PRÁVNE ROZPRAVY ON-SCREEN II. - Sekcia súkromného práva}

online vedecká konferencia - 13. november 2020

právnickou osobou, čo malo dopad na množstvo ako aj na kvalitu rozhodcovských rozhodnutí, pričom kvalita nie vždy zodpovedala primeraným štandardom a v niektorých prípadoch došlo $\mathrm{k}$ podozreniam z účelového prepojenia medzi určitým stálym rozhodcovským súdom a podnikatel'om, ktorý svoje spory opakovane riešil pred daným rozhodcovským súdom. V spojení s (vnímanými, ako aj skutočnými) neduhmi spotrebitel’skej arbitráže tento stav vyvolával nedôveru voči rozhodcovskému konaniu ako takému. Slovenský zákonodarca považoval reguláciu stálych rozhodcovských súdov za dôležitý nástroj verejnej politiky. ${ }^{12}$

Ciel’om, ako vyplýva z dôvodovej správy k zákonu č. 336/2014 Z. z. bolo „obmedzit’ konflikt záujmov medzi zriad’ovatel'om a požiadavka na nestranné a spravodlivé riešenie sporov“. Zároveň sa zákonodarca snažil zamedzit’ tomu, aby bol stály rozhodcovský súd zriadený za účelom generovania zisku pre svojho zriad'ovatel'a, čo zrejme mohlo spôsobit' „absenciu nestrannosti pri rozhodovaní sporov, ktorých účastníkmi sú strany, ktoré generujú podstatnú čast’ sporovej agendy konkrétneho rozhodcovského súdu. “13

Zákonom č. 125/2016 Z. z. nadobudlo ust. § 12 Zákona č. 244/2002 Z. z. od 01.01.2017 znenie, podl'a ktorého „zriad’ovatel’om stáleho rozhodcovského súdu so sídlom na území Slovenskej republiky môže byt' len národný športový zväz alebo komora zriadená zákonom. Právnická osoba je povinná na svoje náklady zriadit' a udržiavat' stály rozhodcovský súd, ak to ustanovuje osobitný predpis.“

Podl’a intertemporálnych ustanovení Zákona č. 125/2016 Z. Z., v ust. § 54c „Stály rozhodcovský súd zriadený podl'a doterajších predpisov, ktorého zriad'ovatel' nespĺn̆a podmienky ustanovené týmto zákonom pre zriad'ovatel'a stáleho rozhodcovského súdu, nemôže po 31. decembri 2016 uskutočňovat' rozhodcovské konania podl’a tohto zákona a vydávat' rozhodcovské rozhodnutia. Rozhodcovské konania podl'a tohto zákona vedené pred stálym rozhodcovským súdom, ktorého zriad’ovatel' po 31. decembri 2016 nespĺn̆a podmienky podl’a právnych predpisov účinných od 1. januára 2017, ktoré začali a v ktorých nebol rozhodcovský rozsudok doručený účastníkom konania pred 1. januárom 2017, sa 31. decembra 2016 zastavujú. Účinky už podaného návrhu na začatie rozhodcovského konania a všetkých d’alších úkonov účastníkov rozhodcovského konania zostávajú zachované, ak účastník konania podá žalobu na súd do troch mesiacov od zastavenia rozhodcovského konania; o výdavkoch rozhodcovského konania, ktoré vznikli účastníkom konania, rozhodne súd podl’a pravidiel o trovách konania. Doba rozhodcovského konania, ktoré bolo zastavené

\footnotetext{
${ }^{12}$ Gyárfáš, J., Števček, M., a kol. . Zákon o rozhodcovskom konaní. Komentár. Praha: C.H. BECK, 2016, s. 225.

${ }^{13}$ Tamtiež, s. 225.
} 


\section{PRÁVNE ROZPRAVY ON-SCREEN II. - Sekcia súkromného práva}

online vedecká konferencia - 13. november 2020

podl'a prvej vety, sa nezapočítava do premlčacej doby podl'a osobitného predpisu. Zriad'ovatel' je povinný zrušit' stály rozhodcovský súd do troch mesiacov odo dňa, ked' podl'a tohto zákona nebude môct' uskutočňovat' rozhodcovské konania a vydávat' rozhodcovské rozhodnutia a súčasne rozhodcovské rozsudky, ktoré stály rozhodcovský súd vydal, nadobudli právoplatnost' bez možnosti podat' žalobu o zrušenie rozhodcovského rozsudku. Ustanovenie odseku 2 sa nepoužije, ak žalobca a žalovaný spoločným vyhlásením do zápisnice pred stálym rozhodcovským súdom najneskôr do 31. decembra 2016 vyjadria súhlas, že rozhodcovské konanie bude d'alej podl'a pravidiel stáleho rozhodcovského súdu a za podmienok tohto zákona prebiehat' ako rozhodcovské konanie vedené pred rozhodcovským súdom zloženým z jedného alebo viacerých rozhodcov. Zmluvné strany nie sú viazané rozhodcovskou zmluvou, ktorá zakladá právomoc stáleho rozhodcovského súdu, ktorého zriad’ovatel' nespíňa podmienky podl’a právnych predpisov účinných od 1. januára 2017, ak do 31. decembra 2016 na jej základe nezačalo rozhodcovské konanie alebo ak rozhodcovské konanie bolo zastavené podl'a odseku 2. To isté platí, ak ide o postup po zrušení rozhodcovského rozsudku podl'a $\S 43$ ods. 2 a stály rozhodcovský súd, ktorý by mal vo veci rozhodovat', bol zrušený.“

Obmedzenia zriad'ovania stálych rozhodcovských súdov sa podl'a uvedených novelizácií týkajú stálych rozhodcovských súdov zriad'ovaných na území Slovenskej republiky. Obmedzenia sa netýka stálych rozhodcovských súdov so sídlom mimo územia Slovenskej republiky. V prípade ak zriad'ovatel' nespĺn̆a podmienky podl'a novely zákona č. 125/2016 Z. Z. a ak rozhodcovské konanie, podl'a tohto zákona, pred takýmto stálym rozhodcovským súdom začalo pred 01.01.2017, ex lege sa 31.decembra zastavuje. Účastník konania má možnost' v lehote troch mesiacov podat' žalobu na všeobecný súd, kedy účinky pôvodne podaného návrhu ako aj účinky všetkých d’alších úkonov účastníkov pôvodne vedeného rozhodcovského konania ostávajú zachované. Účastníci môžu zastavenie rozhodcovského konania odvrátit' taktiež spoločným vyhlásením do zápisnice pred stálym rozhodcovským súdom najneskôr do 31. decembra 2016, kde vyjadria súhlas že rozhodcovské konanie bude d'alej podl'a pravidiel stáleho rozhodcovského súdu a za podmienok tohto zákona prebiehat' ako rozhodcovské konanie vedené pred rozhodcovským súdom zloženým z jedného alebo viacerých rozhodcov; čím de facto dochádza k transformácii rozhodcovského konania na rozhodcovské konanie ad hoc (ad hoc arbitráž).

Zriad'ovatel', ktorý nespíňa nové podmienky pre zriadenie stálych rozhodcovských súdov, je povinný stály rozhodcovský súd zrušit’ v zákonom stanovenej trojmesačnej lehote. 


\section{PRÁVNE ROZPRAVY ON-SCREEN II. - Sekcia súkromného práva}

online vedecká konferencia - 13. november 2020

Pokial' ide o rozhodcovské zmluvy, odkazujúce na stály rozhodcovský súd, ktorého zriad'ovatel' podl'a novej právnej úpravy nie je kvalifikovaným zriad'ovatel'om, tieto sa 1 . Januára 2017 stávajú neúčinné. ${ }^{14}$

O doteraz uvádzaných následkoch novej právnej úpravy (Zákona č. 336/2014 Z. z. ako aj Zákona č. 125/2016 Z. z.) bolo už zmienené v niekol'kých publikovaných odborných prácach, vrátane predchádzajúcich príspevkov autora ${ }^{15}$, kde bolo taktiež poukazované na predpokladanú snahu zriad'ovatel'ov stálych rozhodcovských súdov vyhnút' sa následkom novej obmedzujúcej právnej úpravy a to tak, že zriad'ovatel', ktorý nespĺn̆a podmienky na zriadenie stáleho rozhodcovského súdu, resp. d’alej už nepatrí do okruhu subjektov oprávnených zriad'ovat' stále rozhodcovské súdy, z dôvodu zrejme sa vyhnút' uvedeným následkom vyplývajúcim z ust. § 54c zákona č. 244/2002 Z.z. o rozhodcovskom konaní, V znení novely č. 125/2016 Z.z., premiestni sídlo stáleho rozhodcovského súdu na územie iného štátu. Ku konaniu zriad’ovatel’a uskutočneného v záujme predíst' likvidačným účinkom novej právnej úpravy na doterajšie stále rozhodcovské súdy, môžeme priradit' taktiež kroky zriad'ovatel'a smerujúce k zmene statusu samotného zriad'ovatel'a. Skúsme si preto v krátkosti d'alej uvedené situácie analyzovat' a prípadne poukázat' aj na vybranú existujúcu judikatúru.

V prípade zmien týkajúcich sa samotného zriad’ovatel'a, nová právna úprava takéto zmeny nevylučuje, jedinou podmienkou je, že zriad'ovatel' má spĺn̆at' podmienky na zriadenie stáleho rozhodcovského súdu a teda, že sa má jednat' o jednu z taxatívne určených subjektov v § 12 zákona. Tak ako je možná a zákonom povolená transformácia u obchodných spoločností, nie je možné potom vylúčit' ani zmenu právnej formy niektorých doterajších zriad'ovatel'ov stálych rozhodcovských súdov na právnu formu, ktorá bude zodpovedat' niektorému z vymedzených subjektov $\mathrm{v}$ § 12 zákona, samozrejme pokial' to zákon nezakazuje. V takomto prípade možno argumentum a contrario vyložit', že zriad'ovatel' bude spĺn̆at' podmienky na zriadenie stáleho rozhodcovského súdu aj podl’a novej právnej úpravy, a teda že bude nad'alej patrit' do okruhu subjektov oprávnených zriad'ovat' stále rozhodcovské súdy.

\footnotetext{
14 Tamtiež, s. 683.

${ }^{15}$ Levrinc, M. Základné pojmy rozhodcovského konania vo svetle posledných zmien zákona č. 244/2002 Z. Z. o rozhodcovskom konaní. In Notitiae Novae Facultatis Iuridicae Universitatis Matthiae Belii Neosolii. Roč. 21 Banská Bystrica : Vydavatel'stvo Univerzity Mateja Bela - Belianum, 2017. ISBN 978-80-557-1232-1., s. 229239.
} 


\section{PRÁVNE ROZPRAVY ON-SCREEN II. - Sekcia súkromného práva}

online vedecká konferencia - 13. november 2020

Pri zmene sídla stáleho rozhodcovského súdu však bude situácia úplne iná. V prvom rade je potrebné vysporiadat' sa s pojmom sídlo stáleho rozhodcovského súdu a aký má význam pre samotné rozhodcovské konanie. Zákon o rozhodcovskom konaní sídlo stáleho rozhodcovského súdu bližšie neupravuje. Upravuje však miesto rozhodcovského konania, čo je však diametrálne odlišný pojem. Miesto rozhodcovského konania podriad’uje rozhodcovské konanie pod právny poriadok určitého štátu, ktoré si dohodnú účastníci rozhodcovského konania, prípadne ktoré v prípade absencie takejto dohody určil rozhodcovský súd. Podl’a miesta rozhodcovského konania môžeme určit', či sa jedná o domáce (slovenské) rozhodcovské rozhodnutie, alebo v prípade ak je v zahraničí, či sa jedná o zahraničné rozhodcovské rozhodnutie. Miesto rozhodcovského konania ovplyvňuje rovnako právomoc súdov štátu v mieste rozhodcovského konania na rozhodovanie otázok spadajúcich do kompetencie všeobecných (štátnych) súdov V rozhodcovskom konaní. ${ }^{16}$ Právny poriadok platný v mieste rozhodcovského konania stanovuje požiadavky aj na ustanovenie rozhodcu alebo náležitosti rozhodcovskej zmluvy. Ide teda o miesto, kde má rozhodcovské konanie svoj právny domicil. Nemusí byt' nevyhnutne rovnaké ako miesto konania ústnych pojednávaní, či miesto vykonávania jednotlivých úkonov. ${ }^{17}$ Naopak sídlo stáleho rozhodcovského súdu zákon nepriamo upravuje jedine v ust. § 12 ods.1, kde je vymedzené kto môže byt' zriad'ovatel'om stáleho rozhodcovského súdu so sídlom na území Slovenskej republiky. Zákon nijako nerieši situáciu prípadnej zmeny sídla stáleho rozhodcovského súdu. Pri posudzovaní parciálnych otázok spojených s rozhodcovským konaním, t. zn. napríklad aj oprávnenie rozhodcovského súdu rozhodovat' spory v rozhodcovskom konaní, je významné skúmat' povahu zriad’ovatel'a stáleho rozhodcovského súdu, ktorý zriadil stály rozhodcovský súd so sídlom na území Slovenskej republiky. Pokial' zriad'ovatel' zákonné podmienky nespíňa a teda nepatrí d’alej medzi taxatívne zákonom vymedzené subjekty oprávnené zriadit' stály rozhodcovský súd, podl’a ust. § 54c zákona je povinný zrušit’ stály rozhodcovský súd do troch mesiacov odo dňa, ked' podl'a tohto zákona nebude môct' uskutočňovat' rozhodcovské konania a vydávat' rozhodcovské rozhodnutia. Na povinnost' zriad'ovatel'a zrušit' stály rozhodcovský súd nemá vplyv ani prípadná zmena sídla stáleho rozhodcovského súdu, resp. zákon nespája so zmenou sídla stáleho rozhodcovského súdu odvrátenie likvidačných účinkov na stály rozhodcovský súd podl’a cit. ust. 54c zákona.

\footnotetext{
16 Napr. právomoci pri vzniku a zániku funkcie rozhodcov, alebo napr. právomoc rozhodovat' o zrušení rozhodcovského rozsudku.

${ }^{17}$ Lacko, P., Hrušovský, M. Zákon o rozhodcovskom konaní. Praktický komentár. Bratislava: Wolters Kluwer SR s.r.o., 2020, s. 111.
} 


\section{PRÁVNE ROZPRAVY ON-SCREEN II. - Sekcia súkromného práva}

online vedecká konferencia - 13. november 2020

S otázkou vplyvu zmeny sídla stáleho rozhodcovského súdu na prebiehajúce rozhodcovské konanie, s ohl'adom aj na ust. § 54c zákona, sa zaoberal aj Okresný súd Banská Bystrica, pričom dospel k nasledovným záverom:

Podl'a dostupných informácií na stránke Ministerstva spravodlivosti SR, ešte pred vydaním Rozhodcovského rozsudku, bola vyznačená zmena sídla stáleho rozhodcovského súdu. Takto označený súd nie je totožný so súdom, ktorý mal mat' založenú právomoc podl’a rozhodcovskej doložky obsiahnutej v Zmluve o poskytovaní služieb. Právomoc podl'a tejto doložky mala byt' založená výlučne pre súd identifikovaný ako stály rozhodcovský súd, ktorý mal rozhodovat' $\mathrm{v}$ súlade $\mathrm{s}$ jeho pravidlami a poriadkami uverejnenými $\mathrm{v}$ Obchodnom vestníku. Premiestnenie sídla rozhodcovského súdu zrejme s ciel’om vyhnút' sa zastaveniu prebiehajúcich rozhodcovských konaní, teda právnym účinkom podl’a ust. § 54cods. 2 ZoRK, je potrebné hodnotit' ako obchádzanie zákona a ani zmenou sídla rozhodcovského súdu sa neodvrátia účinky zastavenia prebiehajúceho rozhodcovského konania. V dôsledku inštitucionálnych zmien na strane rozhodcovského súdu (tieto zmeny sa navonok prejavili vyššie uvedenou zmenou sídla spojenou so zmenou samotnej právnej identity súdu) ako aj v dôsledku zákonných zmien podl'a zákona o rozhodcovskom konaní (§ 54c ods. 2) sa rozhodcovská doložka v zmysle Zmluvy o poskytovaní služieb stala neaplikovatel'nou a jej účinky definitívne zanikli najneskôr dňom 31.12.2016. Ak v spojení so zmenou sídla rozhodcovského súdu došlo $\mathrm{k}$ založeniu nového rozhodcovského súdu, tento nemal danú právomoc na vydanie rozhodcovského rozsudku zaväzujúceho Povinného, nakol'ko tu absentuje dohoda strán o založení jeho právomoci. Ak zmenou sídla nedošlo k založeniu nového súdu, potom sa aj po takejto formálnej zmene sídla musí na rozhodcovský súd vzt’ahovat' ZoRK, ktorý je pre všetky stále rozhodcovské súdy predpisom statusovým, teda vzt'ahuje sa na nich aj po akejkol'vek zmene sídla. Z uvedeného vyplýva, že v spojení so zmenou sídla stáleho rozhodcovského súdu došlo bud’ k zániku inštitucionálnej arbitráže oprávnenej rozhodovat' spor podl'a uzatvorenej rozhodcovskej doložky, alebo aj po zmene jeho sídla sa na neho vzt’ahoval ZoRK ako statusový predpis podla ktorého bol tento súd založený, následkom čoho sa všetky rozhodcovské konania neskončené k 31.12.2016 ex lege zastavili. Opísané skutočnosti majú za následok, že na Rozhodcovský rozsudok je potrebné pozerat' ako na právny paakt, ktorý nemôže tvorit' spôsobilý exekučný titul v exekučnom konaní. K obdobným záverom dospel aj Najvyšší súd SR v Uznesení sp. zn. 15XECdo/21/2016 zo dňa 30.06.2016, ked' rozhodcovský rozsudok vydaný na základe 


\section{PRÁVNE ROZPRAVY ON-SCREEN II. - Sekcia súkromného práva}

online vedecká konferencia - 13. november 2020

právomoci vyvodenej $\mathrm{z}$ neplatnej rozhodcovskej zmluvy považoval za právny paakt nespôsobilý byt' exekučným titulom. Rovnaké následky aké Najvyšší súd SR v tomto prípade spojil s neplatnou rozhodcovskou zmluvou sú nevyhnutne spojené aj s konaním súdu bez existujúcej rozhodcovskej zmluvy alebo s vydávaním rozhodnutí po zastavení rozhodcovského konania. ${ }^{18}$

K uvedenému je potrebné dodat', že pri skúmaní možnosti premiestnit’ sídlo stáleho rozhodcovského súdu a skúmaní právnych následkov takéhoto konania je významné posudzovat' otázku statusu stáleho rozhodcovského súdu. Pojmy „rozhodcovský súd“ a „stály rozhodcovský súd“" sa často zamieňajú. Nejde však o synonymá. Rozhodcovský súd tvorí jeden rozhodca alebo viacerí rozhodcovia, ktorí konkrétny spor rozhodujú. Stály rozhodcovský súd je entita (bez právnej subjektivity), ktorá rozhodcovskému súdu pomáha pri zabezpečovaní chodu rozhodcovského konania a ktorá rozhoduje o vybraných otázkach týkajúcich sa ustanovenia rozhodcov a námietkach voči rozhodcom. ${ }^{19}$ Nakol'ko stály rozhodcovský súd nemá právnu subjektivitu je t’ažko si potom predstavit' jeho pôsobenie bez vzt'ahu ku konkrétnemu zriad'ovatel'ovi, na ktorého bez akýchkol’vek výnimiek dopadá povinnost' zrušit' stály rozhodcovský súd pokial' zriad'ovatel' d'alej nesplńa podmienky ustanovené zákonom. Zmena sídla stáleho rozhodcovského súdu, ktorý nemá právnu subjektivitu je sama o sebe nepredstavitel'ná. Ako z doteraz uvedeného vyplýva, ani takáto prípadná zmena sídla by nemala žiaden vplyv na likvidačné povinnosti zriad'ovatel’a vo vzt’ahu k stálemu rozhodcovskému súdu v zmysle zákona č. 125/2016 Z. z., a to aj bez ohl’adu na či by sa rozhodcovské konanie uskutočňovalo mimo územia SR.

\section{Záver}

Prijatím noviel zákona o rozhodcovskom konaní č. 336/2014 Z. z. a č. 125/2016 Z. z. sa významne zmenila možnost' zriad'ovat' stále rozhodcovské súdy, a to v prospech vybraného úzkeho okruhu možných zriad'ovatel'ov so snahou nielen obmedzit' konflikt záujmov medzi zriad'ovatel'om a požiadavkou na nestranné a spravodlivé riešenie sporov, ale určite aj so snahou profesionalizovat' inštitucionalizovanú arbitráž (inštitucionalizované rozhodcovské

\footnotetext{
${ }^{18}$ Uznesenie Okresného súdu Banská Bystrica sp. zn. 56Ek/1982/2019 zo dňa 26.02.2020.

${ }^{19}$ Lacko, P., Hrušovský, M. Zákon o rozhodcovskom konaní. Praktický komentár. Bratislava: Wolters Kluwer SR s.r.o., 2020, s. 61.
} 


\section{PRÁVNE ROZPRAVY ON-SCREEN II. - Sekcia súkromného práva}

online vedecká konferencia - 13. november 2020

konanie). Existujúci dovtedajší počet skoro 200 zriadených stálych rozhodcovských súdov nedával dostatočné záruky na naplńanie uvedených ciel'ov, čo často naznačovala aj samotná prax. So zmenou novej likvidačnej právnej úpravy pre väčšinu stálych rozhodcovských súdov, pred nastúpením jej účinkov, bolo možné prirodzene zo strany zriad'ovatel'ov očakávat' kroky, ktorými by predišli zrušeniu stálych rozhodcovských súdov, zastaveniu ich činnosti, zastaveniu rozhodcovských konaní a zároveň ktorými by predišli neúčinnosti rozhodcovských zmlúv odkazujúcich na stály rozhodcovský súd, ktorého zriad’ovatel' podl’a novej právnej úpravy nie je d’alej kvalifikovaným zriad'ovatel'om. Pri nastolení otázky, či by uvedeným likvidačným účinkom bolo možné predíst' vykonaním zmien na strane zriad'ovatel'a, resp. vykonaním zmien sídla stáleho rozhodcovského súdu by bolo preto potrebné pri zmene sídla stáleho rozhodcovského súdu odpovedat' negatívne. Naviac pôvodná rozhodcovská zmluva ani nepočítala so zmenou sídla stáleho rozhodcovského súdu, ktorý bol zriadený na území Slovenskej republiky podl’a slovenského zákona o rozhodcovskom konaní a ani v cit. ust. § 54c takýto postup nie je právne aprobovaný. V súvislosti so zmenou samotného zriad'ovatel'a stáleho rozhodcovského súdu, pokial' tento bude po vykonanej zmene d'alej splńat' statusové kvalifikačné podmienky na zriad'ovatel'a podl'a novej právnej úpravy a takáto zmena bude vykonaná zákonom aprobovaným spôsobom, bude odpoved' na nastolenú otázku zrejme pozitívna.

\section{ZOZNAM BIBLIOGRAFICKÝCH ODKAZOV}

\section{Monografie, periodiká a zborníky:}

CSACH, K. Intertemporalita novej úpravy rozhodcovského konania. Súkromné právo, 2015, č. 8 .

GYÁRFÁŠ, J., ŠTEVČEK, M., a kol. . Zákon o rozhodcovskom konaní. Komentár. Praha: C.H. BECK, 2016.

LACKO, P., HRUŠOVSKÝ, M. Zákon o rozhodcovskom konaní. Praktický komentár. Bratislava: Wolters Kluwer SR s.r.o., 2020.

LEVRINC, M. Základné pojmy rozhodcovského konania vo svetle posledných zmien zákona č. 244/2002 Z. z. o rozhodcovskom konaní. In Notitiae Novae Facultatis Iuridicae 


\section{PRÁVNE ROZPRAVY ON-SCREEN II. - Sekcia súkromného práva}

online vedecká konferencia - 13. november 2020

Universitatis Matthiae Belii Neosolii. Roč. 21 Banská Bystrica : Vydavatel'stvo Univerzity Mateja Bela - Belianum, 2017.

LYSINA, P., ĎURIŠ, M., HAŤAPKA, M. a kol. Medzinárodné právo súkromné. 2. Vydanie. Bratislava: C. H. BECK, 2016.

ŠTEVČEK, M., FICOVÁ, S., BARICOVÁ, J., MESIARKINOVÁ, S., BAJÁNKOVÁ, J., TOMAŠOVIČ, M., a kol. Civilný sporový poriadok. Komentár. Praha: C.H. BECK, 2016.

\section{Právne predpisy:}

Zákon č. 125/2016 Z.z. o niektorých opatreniach súvisiacich s prijatím Civilného sporového poriadku, Civilného mimosporového poriadku a Správneho súdneho poriadku a o zmene a doplnení niektorých zákonov.

Zákon č. 244/2002 Z.z. o rozhodcovskom konaní.

Zákon č. 336/2014 Z.z., ktorým sa mení a dopĺn̆a zákon č. 244/2002 Z.z. o rozhodcovskom konaní v znení neskorších predpisov a o zmene a doplnení zákona č. 371/2004 Z.z. o sídlach a obvodoch súdov Slovenskej republiky a o zmene zákona č. 99/1963 Zb. Občiansky súdny poriadok v znení neskorších predpisov.

Zákona č. 216/1994 Sb. o rozhodčím řízení a o výkonu rozhodčích nálezů, ve znění pozdějších předpisů (ČR).

\section{Rozhodnutia súdov:}

Ústavný súd ČR, P1. ÚS 37/98.

Uznesenie Najvyššieho súd SR sp. zn. 5 Obdo 20/2012 zo dňa 17.05.2012.

Uznesenie Najvyššieho súdu SR sp. zn. 15XECdo/21/2016 zo dňa 30.06.2016.

Uznesenie Okresného súdu Banská Bystrica sp. zn. 56Ek/1982/2019 zo dňa 26.02.2020.

Uznesenie Ústavného súdu SR Plz. ÚS 5/2015 zo dňa 18.11.2015. 